country rock. In the roof zone of the granite, the sheets become less numerous and more pegmatitic. The granite is essentially post-tectonic, however, the sporadic development of foliation and the symmetrical disposition of the joint orientations about the axial direction of the antiform suggest some residual tectonic influence in the crystallisation stage of the body.

\title{
References
}

Bridgwater, D., Keto, L., McGregor, V. R. \& Myers, J. S. 1976: Archaean gneiss complex of Greenland. In Escher, A. \& Watt, W. S. (edit.) Geology of Greenland, 18-75. Copenhagen: Geol. Surv. Greenland.

McGregor, V. R. 1973: The early Precambrian gneisses of the Godthåb district, West Greenland. Phil. Trans. R. Soc. Lond. A 273, 343-358.

Streckeisen, A. L. 1976: To each plutonic rock its proper name. Earth Sci. Rev. 12, 1-33.

Geology Unit,
Oxford Polytechnic,
Headington,
Oxford OX3 OBP,
U.K.

\section{Geological, geochemical and ecological studies in the Ilímaussaq area, South Greenland}

\author{
John Rose-Hansen and Henning Sørensen
}

In 1978 field work was concentrated on the augite syenites, the lujavrites and the kakortokites in the southern part of the area and on the environmental geochemistry and the ecology of the Narssaq area. Some preliminary results of the field and laboratory investigations are reported below.

Rare-earth elements in the waters of the Narssaq area (Carsten Langtofte Larsen)

As part of the investigations of the exogenous geochemistry of the region (Bohse et al., 1975; Nielsen et al., 1976; Rose-Hansen \& Sørensen, 1977, 1978) a method of preconcentration of rare-earth elements, thorium and hafnium from water has been developed by H. A. van der Sloot and C. L. Larsen. One litre of water is forced by a pressure column through a $0.4 \mu \mathrm{m}$ filter. The filtered water is mixed with sodium oxalate and activated carbon. After thorough shaking the carbon is separated from the water in a radiochemical chimney on a $0.8 \mu \mathrm{m}$ filter and is studied by neutron activation analysis. Samples have been collected in three main rivers, Narssaq Elv, Lilleelv and Lakseelv, their tributaries and adjoining lakes; in rivers and lakes of a reference area in Julianehåb granite; and in the 
fjords. The temperature, conductivity and $\mathrm{pH}$ of the water have been measured in all samples.

\section{Marine biology (Martin Munk Hansen)}

Activity has been concentrated on material collected during the years 1974-1976.

Instrumental neutron activation analysis of material collected during 1976 (mainly mussels and seaweed) is nearly complete. For comparison, material from Kronprinsens Ejland (south of Disko), Mârmorilik (West Greenland) and Isefjord (Denmark) has been analysed. Several computer programmes for the interpretation of the analyses have been designed:

(1) Regression analysis of elements with size-specific concentrations and plotting of results.

(2) Graphical comparison of concentrations.

(3) Correlation analysis.

\section{Hydrology and hydrogeochemistry (Niels P. Christensen)}

Two automatic meteorological and hydrological stations (Christensen, 1976; Rose-Hansen, Nielsen \& Sørensen, 1977) are operating in the Narssaq river valley and a granite reference area. River discharge, precipitation, air, soil and river water temperature, wind speed and direction, incoming radiation, air pressure and humidity are registered every two and three hours in the reference area and Narssaq river valley respectively. The automatic station's Aanderaa dataloggers (type DL-1) have given rise to a number of problems. Successive flooding of the Narssaq station and short-circuiting caused by condensed water have resulted in battery exhaustion and logging stops. Consequently the original plastic tube casing was replaced by a fibre glass covered wooden box in 1978. Another problem has been rust clogging the narrow tube connecting the precipitation gauge to the transducer which measures the pressure of the water column. Rust formation is now prevented by addition of a strongly reducing compound to the gauge.

Conversion formulae for all channels have now been completed. Since the pressure transducers are specially adapted for use in the Narssaq Project, calibrations of these sensors have been routine for the last two years. There are now four river transducers and two precipitation transducers in constant operation. Conversions for other sensors are supplied by Aanderaa.

In March, July and August of 1978 more than a hundred samples of stream water, snow and rainwater were collected for chemical analyses. The samples are now being analysed for $\mathrm{Na}, \mathrm{K}, \mathrm{Mg}$ and $\mathrm{Ca}$ and will later be analysed for $\mathrm{Pb}, \mathrm{Zn}, \mathrm{Cu}, \mathrm{Cd}$ and $\mathrm{F}$ as well as for $\mathrm{Cl}, \mathrm{SiO}_{2}$, $\mathrm{Fe}, \mathrm{Mn}, \mathrm{HCO}_{3}^{-}$and a number of other constituents. The ratio ${ }^{16} \mathrm{O} /{ }^{18} \mathrm{O}$ in precipitation and a few water samples is being determined by mass spectrometry.

Geochemical studies of rocks and minerals (J. Bailey, H. Bohse, A. Demina, R. Gwozdz, J. Rose-Hansen \& H. Sørensen)

A detailed study of the distribution of $\mathrm{ZrO}_{2}$ in a $200 \mathrm{~m}$ deep drill hole through aegirine lujavrite I, Ilimaussaq instrusion has been undertaken by XRF analysis. 
The transitional layered kakortokites and the overlying aegirine lujavrite I possess mean $\mathrm{ZrO}_{2}$ contents of 1.3 per cent and 1.1 per cent, respectively. Together they contain approximately 25 million tons $\mathrm{ZrO}_{2}, 9$ million tons $\mathrm{RE}_{2} \mathrm{O}_{3}$ and 2 million tons $\mathrm{Nb}_{2} \mathrm{O}_{5}$.

\section{Table 6. Mean Li and $F$ values (ppm) for Ilimaussaq lujavrites}

\begin{tabular}{lrrrr} 
& No of & \\
& samples & Li & $F^{*}$ \\
\hline Aegirine lujavrite I (Kangerdluarssuk) & 179 & 160 & 600 \\
Later aegirine lujavrites (Tunugdliarfik) & 11 & 160 & 900 \\
Arfvedsonite lujavrite (Tunugdliarfik) & 19 & 630 & 1900 \\
Arfvedsonite lujavrite (Kvanefjeld) & 21 & 750 & 8500 \\
Med. to coarse grained lujavrite (Kvanefjeld) & 42 & 750 & 2000 \\
Naujakasite lujavrite (Kvanefjeld) & 18 & 700 & 4500 \\
Villiaunite-bearing lujavrite (Kvanefjeld) & 29 & 760 & 9600 \\
\hline *Preliminary results & †g800 (specific-ion electrode)
\end{tabular}

The distribution of lithium and fluorine in lujavrites from the Ilímaussaq intrusion has been studied by Čerenkov counting following neutron activation analysis and by specific-ion (F) electrode. The $\mathrm{Li}$ and $\mathrm{F}$ values are shown in Table 6. Mean $\mathrm{Li}$ values show an overall increase from $160 \mathrm{ppm}$ in aegirine lujavrite I from Kangerdluarssuk to $630 \mathrm{ppm}$ in arfvedsonite lujavrite from the Tunugdliarfik area to $750 \mathrm{ppm}$ in medium to coarse grained lujavrite from Kvanefjeld. The F values show the same increasing trend as $\mathrm{Li}$.

\section{References}

Bohse, H., Larsen, L. M., Rose-Hansen, J., Nielsen, C. O. \& Sørensen, H. 1975: Current research on the Ilímaussaq alkaline intrusion, South Greenland. Rapp. Grønlands geol. Unders. 75, 81-83.

Christensen, N. P. 1976: The use of dataloggers. Rapp. Grønlands geol. Unders. 85, 70-72.

Nielsen, C. O., Rose-Hansen, J. \& Sørensen, H. 1976: Environmental, geochemical and ecological studies in the region around the Ilimaussaq alkaline intrusion, South Greenland. Rapp. Grønlands geol. Unders. 80, 93-97.

Rose-Hansen, J. \& Sørensen, H. 1977: Current research in the Ilímaussaq region, South Greenland. Rapp. Grønlands geol. Unders. 85, 67-73.

Rose-Hansen, J. \& Sørensen, H. 1978: Geological, geochemical and ecological research in the Ilímaussaq region, South Greenland. Rapp. Grønlands geol. Unders. 90, 67-73.

Rose-Hansen, J., Nielsen, C. O. \& Sørensen, H. (edit.) 1977: The Narssaq project. A geochemical-ecological project. Progress report no. 1. The 1974 field season. Vol. I \& II. Inst. Petrology, Univ. Copenhagen, $122 \mathrm{pp}$.

Institut for Petrologi, University of Copenhagen, $\emptyset$ ster Voldgade 10, $D K-1350$ Copenhagen $K$. 